\title{
DURABILITY ASSESSMENT OF MONOLITHIC RAMMED EARTH WALLS
}

\section{P. L. NARLOCH ${ }^{1}$, P. WOYCIECHOWSKI ${ }^{2}$, E.DMOWSKA ${ }^{3}$, K.HALEMBA $^{4}$}

One of the main threats to constructions made from rammed earth is destruction due to exposure to water. The way to limit this dangerous phenomenon is to supplement the local soil mixtures with stabilizing agents. The main component used is Portland cement. This article analyses the results of research which focused on the resistance of rammed earth to water erosion. Because of the lack of national standards regarding the method of examining the durability of rammed earth, the research was based on the New Zealand standard NZS 4298: 1998. The results confirm the possibility of using rammed earth stabilized by cement in a temperate climate.

Keywords: rammed earth, erosion test, durability

\section{INTRODUCTION}

In a temperate climate weather conditions have a significant impact on the durability of vertical partitions made from rammed earth. However, monolithic walls made from a mixture of soils without stabilizing additives may attain compressive strength that allows them to perform a loadbearing function [7]. Rammed earth stabilized with cement binder is a type of low but controlled strength material.

\footnotetext{
${ }^{1}$ Msc., Eng., Warsaw University of Technology, Faculty of Civil Engineering, Al. Armii Ludowej 16, 00-637 Warsaw, Poland, e-mail: p.narloch@il.pw.edu.pl

${ }^{2}$ DSc., PhD., Eng., Warsaw University of Technology, Faculty of Civil Engineering, Al. Armii Ludowej 16, 00-637 Warsaw, Poland, e-mail: p.woyciechowski@il.pw.edu.pl

${ }^{3}$ Warsaw University of Technology, Faculty of Civil Engineering, Al. Armii Ludowej 16, 00-637 Warsaw, Poland, e-mail: dmowska.ewa@gmail.com

${ }^{4}$ Warsaw University of Technology, Faculty of Civil Engineering, Al. Armii Ludowej 16, 00-637 Warsaw, Poland, e-mail: khal@wp.pl
} 
In such a case, stabilization of mechanical properties is crucial in terms of usefulness, as it could be visible on the example of CLSM (controlled low-strength materials) such as flowable fill [10]. Apart from the issue of strength, the rammed earth walls could be prone to corrosion due to water exposure [1,3].

The only Polish guidelines regarding rammed earth were published in the 1960's. These are the trade standards BN-62-6738-01 and BN-62-6738-02 and according to the Polish Committee for Standardization, they can contain out-of-date technical data. Therefore there is a need to determine the methods of assessment of durability with the use of modern technologies and with reference to standards that are in operation in other developed countries [5].

Currently, the two regions that have the greatest accumulated knowledge in terms of modern rammed earth constructions are Australia and New Zealand [6] and USA, New Mexico [2]. In terms of durability research of rammed earth, one of the best and most workable methods appear in the New Zealand standard NZS 4298: 1998 [9]. Due to the similar climate conditions of Poland and southern New Zealand, the research methods may also be used in Polish conditions. Based on the methodology of durability assessment used in the above mentioned standard, a durability analysis of rammed earth was performed. The samples differed depending on the used amount of the stabilizing additive in the form of Portland cement CEM I 42.5R and the granular composition of the soil mixture. This article presents the research equipment built by the authors, constructed according to the guidelines described in the New Zealand standard, the measurements taken, and the results and conclusions of the performed research.

\section{SOIL MIXTURES USED FOR RESEARCH}

Before beginning his research the author performed a literature analysis of the recommended granular composition of the rammed earth mixtures. According to W. Maniatidis and P. Walker soil mixtures, that do not contain stabilizing additives, should have clay and silt fractions at the $20-35 \%$ level and the gravel and sand fractions at the $50-75 \%$ level [6]. For soil mixtures stabilized by cement similar ratios are recommended - $25-40 \%$ of clay and silt fractions and $60-75 \%$ of sand and gravel fractions (Fig. 1) [6]. The compressive strength research done by M. Hall and Y. Djerbib have shown that the highest values are acquired when using mixtures which contain $30 \%$ clay and silt fractions and $70 \%$ sand and gravel fractions [4].

Furthermore, the above mentioned authors have formed a hypothesis according to which the key influence on the value of compressive strength of unstabilized earth is the ratio of clay and silt 
fractions to sand and gravel fractions and a secondary influence is the character of granular composition curve [4]. According to the above information the authors of this article have prepared four soil mixtures with a 3 to 7 ratio of clay and silt fractions to sand and gravel fractions.

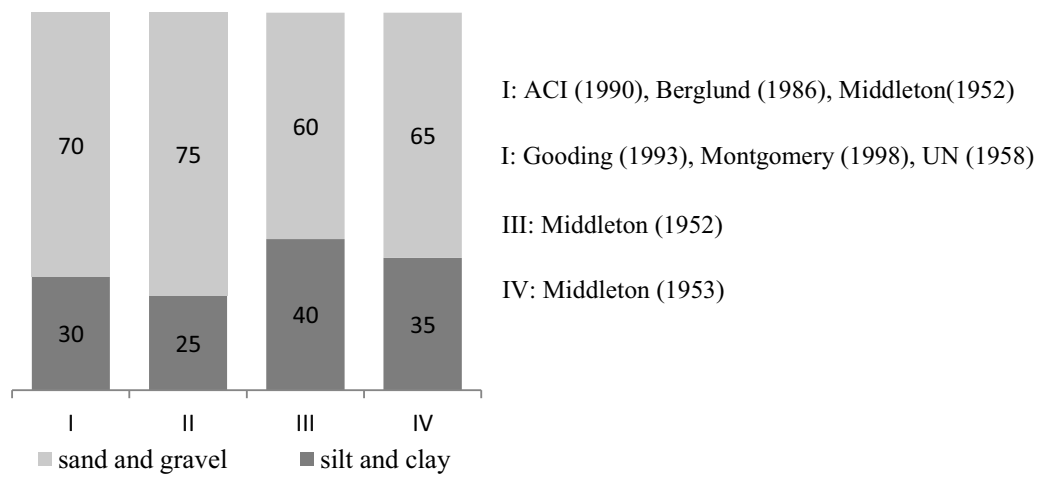

Fig. 1. Recommendations regarding proportions of the mixtures containing cement [6]

Each mixture was different from the others in terms of the ratio of sand and gravel fractions. Each of the four mixtures was prepared in three variants - without the stabilizing agent and also with the addition of Portland cement CEM I 42.5R in the amount of $6 \%$ and $9 \%$ of the soil mixture mass. An overview of all of the designed component combinations are shown in Fig. 2.

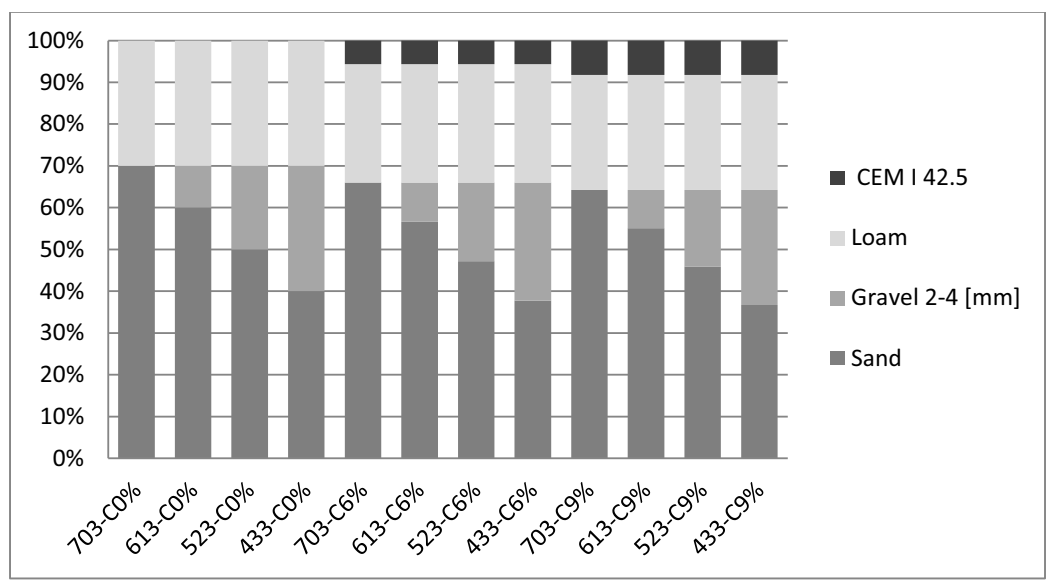

Fig. 2. Composition of soil mixtures used for research 
Upper Triassic loam used in the mixture came from an open deposit in Szkucin. This type of loam was used for the research because the supplier guaranteed that granular composition of the loam would classify it as silt clay that does not contain a sand fraction. Furthermore the chemical and mineral composition of this loam was provided. The overview of these characteristics of the loam is featured in table 1. Before mixing with other ingredients the loam was grinded into a meal with the granularity of $0-1 \mathrm{~mm}$. The granularity of the sand used in the research is shown in table 2 and the granularity of gravel was $2-4 \mathrm{~mm}$. The above ingredients were dried into a stable mass with the temperature of $60^{\circ} \mathrm{C}$ and then mixed with each other and with cement.

Table 1. Properties of loam used for the research - data from the producer [11]

\begin{tabular}{|c|c|c|c|c|c|}
\hline \multicolumn{2}{|c|}{$\begin{array}{c}\text { Chemical composition } \\
{[\%]}\end{array}$} & \multicolumn{2}{|c|}{$\begin{array}{c}\text { Mineral composition } \\
{[\%]}\end{array}$} & \multicolumn{2}{|c|}{$\begin{array}{c}\text { Granular composition of raw loam } \\
\text { (before grinding) }\end{array}$} \\
\hline $\mathrm{SiO}_{2}$ & $55.00-62.14$ & quartz & $17-25$ & $>100 \mu \mathrm{m}$ & $<2.4 \%$ \\
\hline $\mathrm{Al}_{2} \mathrm{O}_{3}$ & $15.70-17.70$ & kaolinite & $3-10$ & $<60 \mu \mathrm{m}$ & $96.3-99.9 \%$ \\
\hline $\mathrm{Fe}_{2} \mathrm{O}_{3}$ & $6.09-7.90$ & illite & $3-10$ & $<40 \mu \mathrm{m}$ & $93.1-99.2 \%$ \\
\hline $\mathrm{TiO}_{2}$ & $0.70-0.90$ & hematite & $3-5$ & $<20 \mu \mathrm{m}$ & $80.8-93.9 \%$ \\
\hline $\mathrm{K}_{2} \mathrm{O}$ & $2.90-3.50$ & plagioclase & $<3$ & $<6 \mu \mathrm{m}$ & $49.3-72.8 \%$ \\
\hline $\mathrm{CaO}$ & $0.33-0.81$ & potassium feldspar & $<3$ & $<2 \mu \mathrm{m}$ & $24.7-46.5 \%$ \\
\hline $\mathrm{MnO}$ & $0.04-0.17$ & goethite & $<2$ & $<0.5 \mu \mathrm{m}$ & $9.3-20.2 \%$ \\
\hline $\mathrm{Na}_{2} \mathrm{O}$ & $0.06-0.26$ & anatase & $<5$ & $<0.2 \mu \mathrm{m}$ & $0.6-9.2 \%$ \\
\hline $\mathrm{P}_{2} \mathrm{O}_{5}$ & $0.05-0.18$ & mixed layer minerals & $32-53$ & & \\
\hline $\mathrm{MgO}$ & $2.20-3.20$ & amorphous phase & 15 & & \\
\hline
\end{tabular}

Table 2. Mesh analysis of Vistula river sand used for research

\begin{tabular}{|c|c|}
\hline Granular composition of the sand & $\%$ of mass \\
\hline$>0.2 \mathrm{~cm}$ & $0.91 \%$ \\
\hline$>0.1 \mathrm{~cm}$ & $5.03 \%$ \\
\hline$>0.05 \mathrm{~cm}$ & $24.80 \%$ \\
\hline$>0.025 \mathrm{~cm}$ & $56.23 \%$ \\
\hline$>0.0125 \mathrm{~cm}$ & $13.03 \%$ \\
\hline
\end{tabular}

After acquiring a homogenous, mixture water was added to help the mixture attain the projected moisture content. The New Zealand Standard NZS 3298:1998 recommends that the mixtures used for construction have a moisture content that is not lower than 3\% and not higher than $5 \%$ from the optimum moisture content [9]. The measurements of the density rate via the Proctor method have shown that the optimum moisture content for unstabilized soil mixtures is from 7 to $9 \%$. This was the basis of the average moisture content value of the samples which was $8 \%$ for each of the mixtures. 


\section{THE METHOD OF DURABILITY ASSESSMENT}

The durability assessment of rammed earth elements uses many methods, some of which include:

- water absorbability tests of rammed earth samples,

- wet to dry strength approach tests of both types of rammed earth samples,

- freeze resistance tests,

- water erosion tests (spray tests, drip tests, wet/dry appraisal tests).

The results of each of the above mentioned tests carry different information about the characteristics of rammed earth samples and, as such, determines that their durability would require performing of all of the tests and measurements. This article analyses the results of soil sample tests that have been subjected to a two-stage water erosion test that has been described in the New Zealand standard NZS 4298: 1998 [9]. According to this standard the samples should first be subjected to a pressure spray method erosion testing and then to a wet/dry appraisal test.

The first of the above mentioned tests has the goal of determining the water erosion ratio and according to this ratio the second test is performed - the length of the six cycles of water absorption of side surfaces of the samples which then undergo a drying process.

The durability assessment of rammed earth elements includes many methods, some of which are:

- water absorbability tests of rammed earth samples,

- wet to dry strength approach tests of both types of rammed earth samples,

- freeze resistance tests,

- water erosion tests (spray tests, drip tests, wet/dry appraisal tests).

The results of each of the above mentioned tests carry different information about the characteristics of rammed earth samples and, as such, determines their durability would require performing of all of the tests and measurements. This article analysis the results of soil sample tests that have been subjected to a two-stage water erosion testing that has been described in the New Zealand standard NZS 4298: 1998 [9].

According to this standard the samples should first be subjected to a pressure spray method erosion testing and then to a wet/dry appraisal test. The first of the above mentioned tests has the goal of determining the water erosion ratio and according to this ratio the second test is performed - the length of the six cycles of water absorption of side surfaces of the samples which then undergo a drying process. 


\subsection{THE SAMPLES USED FOR THE PRESSURE SPRAY METHOD}

Wall samples with the dimensions 30x30x20 cm were constructed. These elements were rammed in formworks made out of waterproof shuttering plywood, the same type that is used when constructing objects - both from rammed earth and from concrete.

The samples were moulded by laying them down and then ramming five layers of the mixture that were six centimetres deep. Each of the layers was compacted with a $6.5 \mathrm{~kg}$ grinder, until each of the mixture layers attained the density value set in the Proctor test. After finishing the forming, samples were left for 24 hours in the formworks, and then demolded and conditioned for 27 days in relatively high air humidity and in a temperature of $20^{\circ} \mathrm{C}$.

\subsection{THE DESCRIPTION OF THE PRESSURE SPRAY METHOD}

The water erosion test was applied to a fragment of the side surface of the samples. This fragments (in the shape of a circle with a diameter of $15 \mathrm{~cm}$ ) was exposed to a jet of water with a pressure of $50 \mathrm{kPa}$. The testing lasted for an hour or until the water would pierce through the sample.

For the purpose of the research, a research apparatus was constructed (Fig. 3, Fig. 4, Fig. 5) and the scheme of this machine (Fig. 1, Fig. 2) was published and described in appendix D of the NZS 3298:1998 standard.

The main elements of the apparatus were a pipe with a $1 / 2$ inch diameter, a water pressure reduction, a manometer with the range of 0-1 bar and a spraying nozzle. To precisely represent the spraying nozzle that was featured in the standard it was decided that it would be constructed from acrylonitrile butadiene styrene (ABS) using 3D printing technology (Fig. 4). The apparatus leaned against a frame made of bars and waterproof plywood. The sample that was tested was put behind a wall that featured a circular opening with a diameter of $150 \mathrm{~mm}$ and that was $470 \mathrm{~mm}$ away from the spraying nozzle.

According to the measurement procedure, the testing of each sample was done in 15 min intervals to examine the depth of the erosion. The erosion depth (D) was determined for each sample by using a bar with a diameter of $10 \mathrm{~mm}$, with a flat ending to probe the most washed out part of the sample after an hour. 


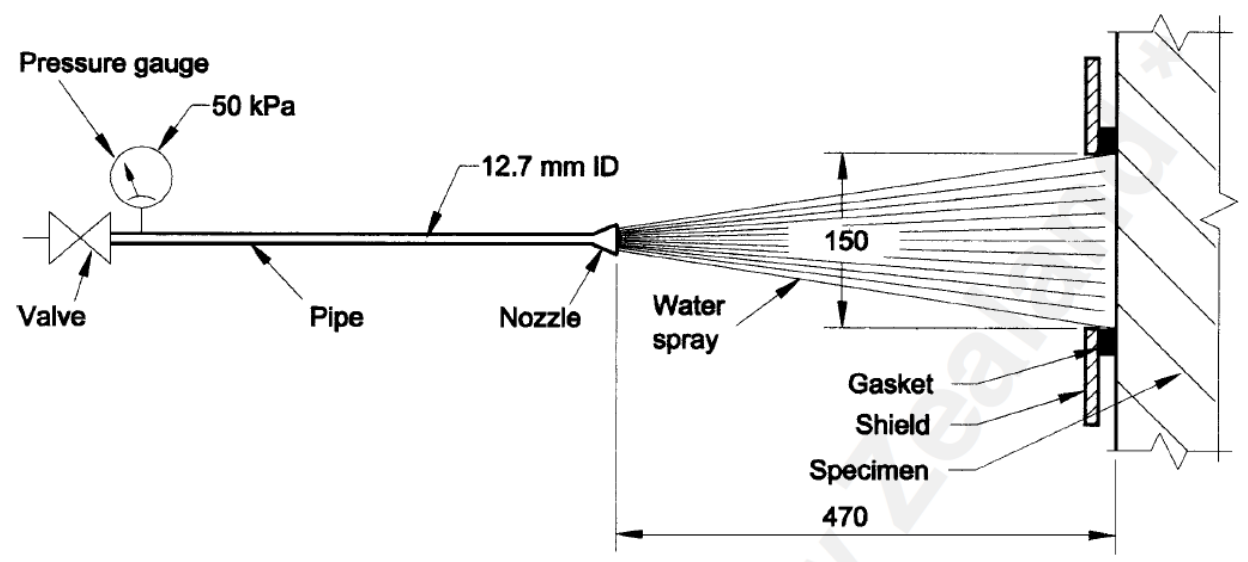

Fig.3. Pressure spray test general arrangement according to NZS 4298: 1998 [6]

In the case when the sample was pierced through in a period shorter than one hour, the erosion depth was determined as a quotient of the thickness of the sample and the time needed for full erosion $[\mathrm{mm} / \mathrm{h}]$.

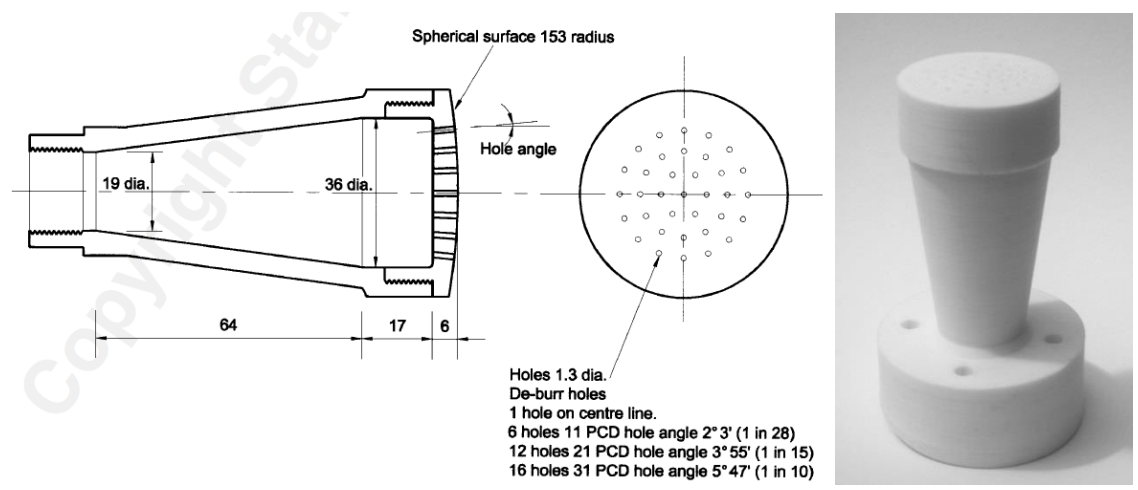

Fig. 4. On the left: Scheme of the spray nozzle according to NZS 4298: 1998.

On the right: The spray nozzle made of plastics using 3D-printing technology 


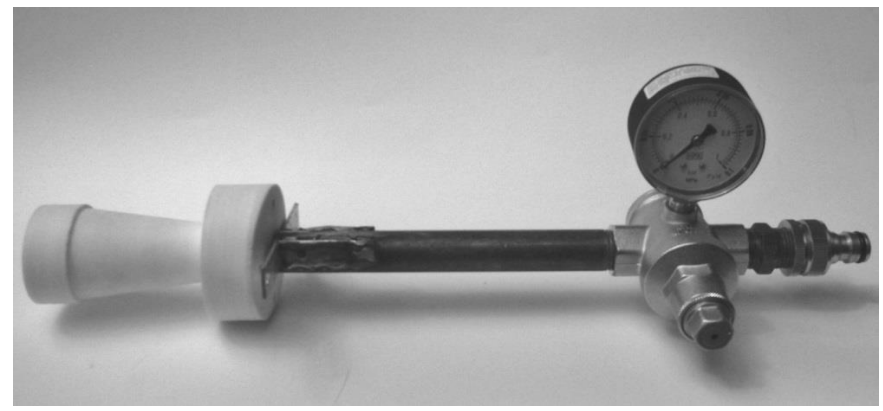

Fig.5. Equipment used for research

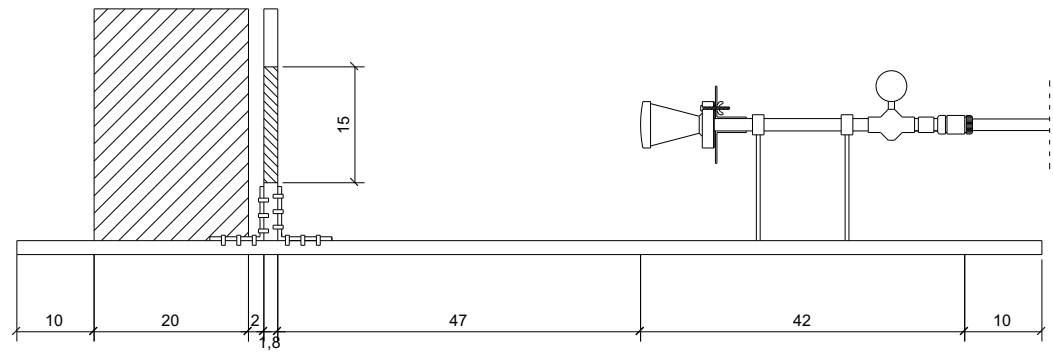

Fig. 6. The scheme of the constructed research stand

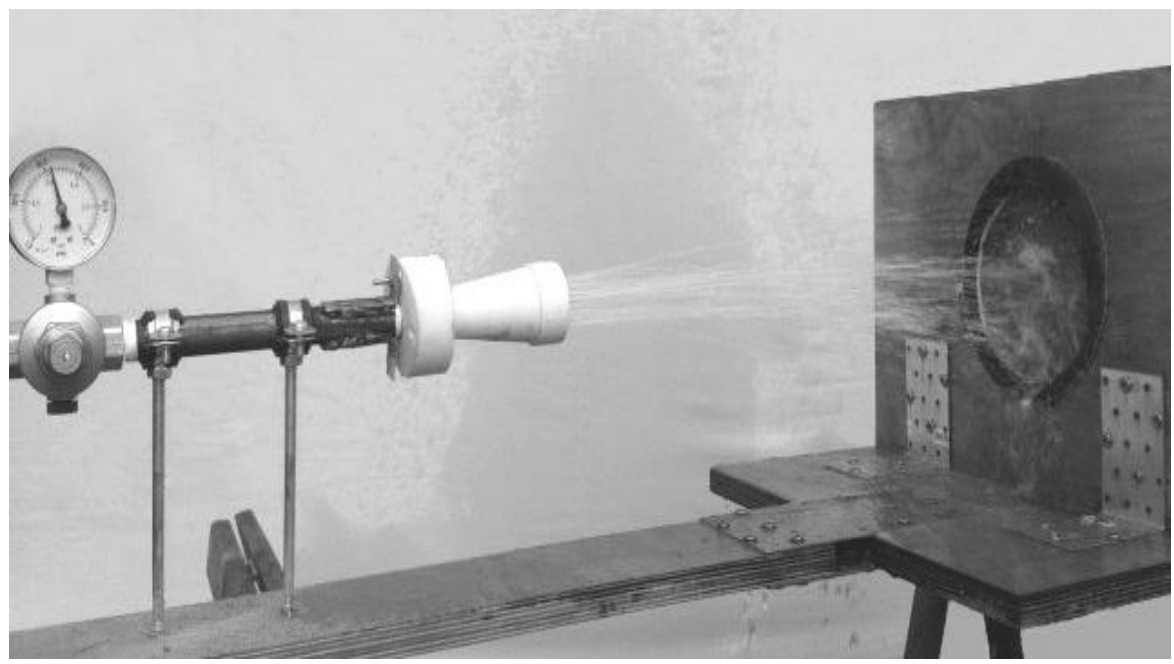

Fig.7. Sample testing 


\subsection{THE RESULTS OF THE PRESSURE SPRAY METHOD TESTING}

The results of the water erosion tests are collated in table 3 and the surface deteriorations of samples are visible on fig 8 .

Table 3. The overview of the erodibility tests. The depth of the erosion D is given in [mm]

\begin{tabular}{|c|c|c|c|c|c|c|c|c|c|c|c|c|c|}
\hline \multirow{2}{*}{$\begin{array}{c}\text { TIME OF } \\
\text { EXAMINATION }\end{array}$} & 433 & 523 & 613 & 703 & 433 & 523 & 613 & 703 & 433 & 523 & 613 & 703 \\
\cline { 2 - 14 } & \multicolumn{3}{|c|}{$9 \%$ CEM I } & \multicolumn{3}{|c|}{$6 \%$ CEM I } & \multicolumn{3}{|c|}{$0 \%$ CEM I } \\
\hline 15 min. & 1 & 0 & 0 & 0 & 1 & 0 & 0 & 0 & 3 & 5 & 21 & 24 \\
\hline $30 \mathrm{~min}$. & 1 & 0 & 0 & 1 & 2 & 0 & 0 & 0 & 9 & 11 & 29 & 33 \\
\hline $45 \mathrm{~min}$. & 1 & 1 & 1 & 2 & 2 & 0 & 0 & 0 & 15 & 16 & 36 & 45 \\
\hline $60 \mathrm{~min}$. & 1 & 1 & 1 & 2 & 2 & 0 & 0 & 0 & 20 & 19 & 53 & 53 \\
\hline
\end{tabular}

433 9\% cement

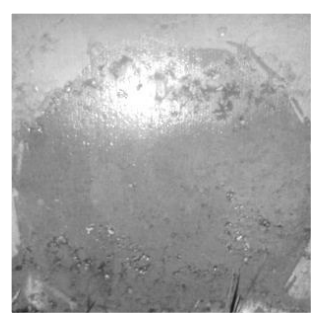

$5239 \%$ cement

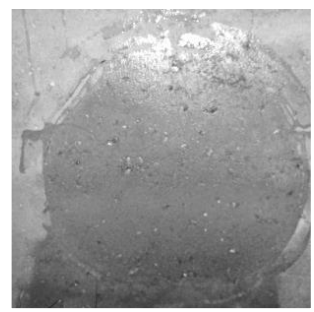

$4336 \%$ cement

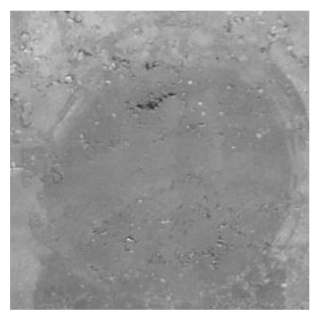

$5236 \%$ cement

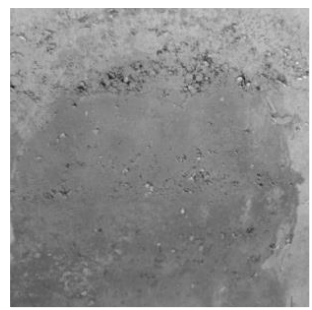

$4330 \%$ cement

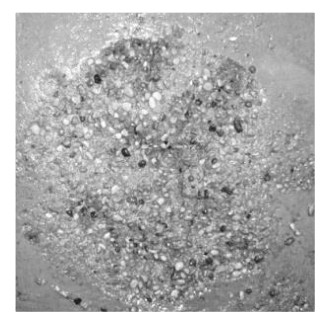

$5230 \%$ cement

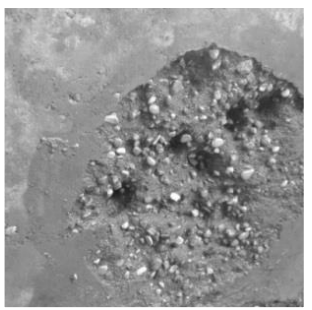

Fig. 8. Surface of the samples after the completion of the first stage of research 


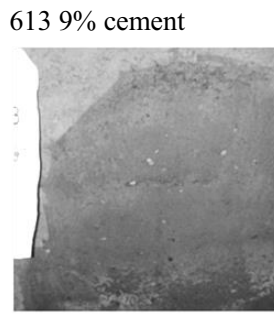

$7039 \%$ cement

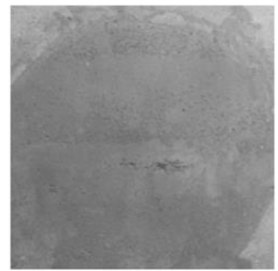

$6136 \%$ cement

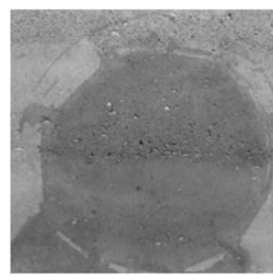

$7036 \%$ cement

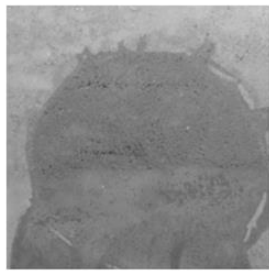

$6130 \%$ cement

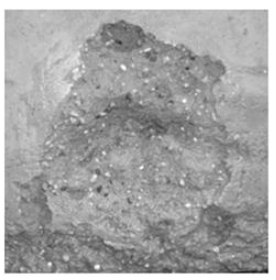

$7030 \%$ cement

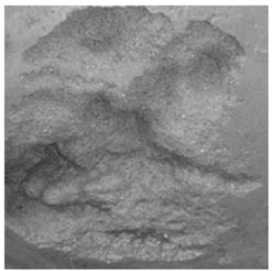

Fig. 8. Surface of the samples after the completion of the first stage of research - continued

The erodibility ratios have been determined according to table 4. On the grounds of erosiveness research the samples have been assigned to an appropriate group (table 5).

Table 4. Determination of the ratio of susceptibility to water erosion according to NZS 4298: 1998 [6]

\begin{tabular}{|c|c|}
\hline Benchmark $\mathrm{D}[\mathrm{mm} / \mathrm{h}]$ & Erodibility ratio \\
\hline $0 \leq \mathrm{D}<20$ & 1 \\
\hline $20 \leq \mathrm{D}<50$ & 2 \\
\hline $50 \leq \mathrm{D}<90$ & 3 \\
\hline $90 \leq \mathrm{D}<120$ & 4 \\
\hline $\mathrm{D} \geq 120$ & 5 (the sample should be discarded) \\
\hline
\end{tabular}

Table 5. Classification of the samples according to the erodibility ratio

\begin{tabular}{|c|c|}
\hline Erodibility ratio & Samples \\
\hline 1 & All with the addition of cement and 523 without cement \\
\hline 2 & 433 without cement \\
\hline 3 & 613 and 703 without cement \\
\hline
\end{tabular}

After assigning the mixtures to the appropriate groups the authors went on to the second stage of the research - a cyclical wet and dry appraisal test. 


\subsection{CYCLIC WET AND DRY APPRAISAL TESTING}

The goal of the testing was to eliminate soil mixtures that could be destroyed after a given number of wet and drying cycles despite having positive strength results. Further deciding factors were the mineral composition, incorrect overall composition or poor production process.

\subsubsection{PREPARING THE SAMPLES}

In the tests cubic samples were used with the side dimension of $100 \mathrm{~mm}$, which were prepared as described in [4] and [8]. It consisted of ramming a wet mixture put in three equal layers using a grind with a mass of $6.5 \mathrm{~kg}$. Each of the layers was molded by loosely dropping the grinder from $30 \mathrm{~cm}$ above the surface of the sample. This was done twenty times. The samples after demolding were seasoned in the same way as the samples tested by pressure spray testing.

\subsubsection{TEST DESCRIPTION}

This test consisted of dipping the side surfaces of the samples in water - in the case of external partitions these surfaces are the most susceptible to impact of adverse weather conditions. After assigning the samples, based on the water erosion ratio, to each group, the same samples were then exposed to water. This exposure lasted a given time (table 6).

Table 6. Time of water exposure of rammed earth samples depending on water erodibility ratio

\begin{tabular}{|c|c|}
\hline Ratio of susceptibility to water erosion & Time of water exposure in [min] \\
\hline 1 & 4 \\
\hline 2 & 2 \\
\hline 3 & 1 \\
\hline 4 & 0.5 \\
\hline
\end{tabular}

The samples were laid out in flat vessels filled with water to the level of $10 \mathrm{~mm}$, on several two millimeter distance discs, thanks to which almost the whole surface of the submerged wall was in constant contact with water. The test used Polish two zloty coins as distance discs because they were equal in size to New Zealand 20 cent coins. After removing the samples from the vessel they were dried 24 hours or until they gained the coloration that was the same as the control sample. The test was repeated 6 times, the same sample walls were tested. After the completion of the testing the samples were left to dry for 2 days and then compared to the control samples. 


\section{RESEARCH RESULTS}

The results of the research are collated in table 7 . None of the samples that contained the $6 \%$ or $9 \%$ cement addition showed any surface damage in comparison to the control samples. In turn, all of the samples without the addition of the cement that were tested had deep defects (Fig. 9), despite the shorter time of water exposure, resulting from the ratio of water erosion susceptibility.
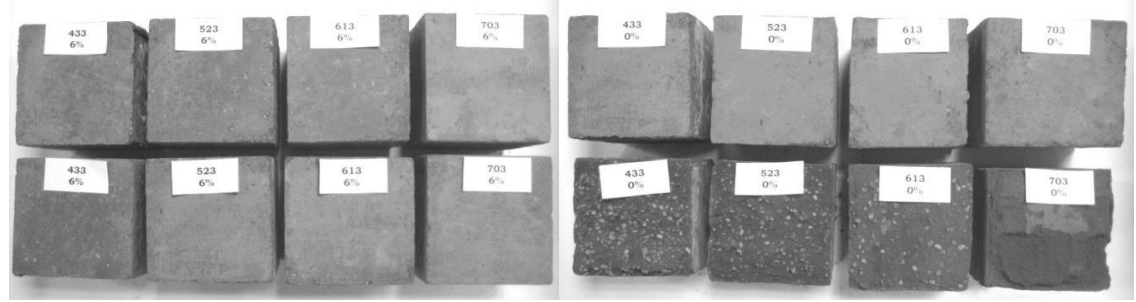

Fig. 9. Sample assessment after the cyclical wet and dry testing. Left: samples from the mixtures stabilized by $6 \%$ of CEM I. Right: samples from mixtures with the addition of cement. Upper rows: comparison samples. Lower rows: samples after the research.

Table 7. Overview of the research results of cyclical wet and dry appraisal testing

\begin{tabular}{|c|c|c|c|c|}
\hline $\begin{array}{l}\text { Soil mixture } \\
\text { composition }\end{array}$ & $\begin{array}{l}\text { The status } \\
\text { of the check sample } \\
\text { surface }\end{array}$ & Erodibility ratio & $\begin{array}{l}\text { Time of water } \\
\text { exposure }\end{array}$ & $\begin{array}{l}\text { Description } \\
\text { of the changes of the } \\
\text { surface of the sample } \\
\text { after the exposure }\end{array}$ \\
\hline $433-0 \%$ CEM & \multirow{12}{*}{ NO DAMAGE } & 2 & $6 \times 2 \min$ & \\
\hline $523-0 \%$ CEM & & 1 & $6 \times 4 \min$ & deep losses on \\
\hline $613-0 \%$ CEM & & 3 & $6 \times 1 \mathrm{~min}$ & whole sample \\
\hline $703-0 \%$ CEM & & 3 & $6 \times 1 \mathrm{~min}$ & \\
\hline $433-6 \%$ CEM & & \multirow{8}{*}{1} & \multirow{8}{*}{$6 \times 4 \mathrm{~min}$} & \multirow{8}{*}{ NO DAMAGE } \\
\hline $523-6 \%$ CEM & & & & \\
\hline $613-6 \%$ CEM & & & & \\
\hline $703-6 \%$ CEM & & & & \\
\hline $433-9 \%$ CEM & & & & \\
\hline $523-9 \%$ CEM & & & & \\
\hline $613-9 \%$ CEM & & & & \\
\hline $703-9 \%$ CEM & & & & \\
\hline
\end{tabular}




\section{ANALYSIS OF RESULTS AND CONCLUSIONS}

The analysis of the acquired results can lead to the following conclusions:

- The mixtures without the stabilizing agent easily succumb to water erosion and cannot be used in external partitions that are susceptible to climate conditions.

- The proportions of the sand and gravel fraction in the soil mixture have a secondary impact on the resistance to water erosion.

- The usage of cement improves the durability of the material in water erosion conditions.

- Both the samples that had $6 \%$ of cement mass addition, as well as those that had $9 \%$ of cement, positively passed the water erosion durability tests.

- To further optimize the composition of the mixture analogous research for samples will less cement content should be performed.

The positive results of water erosion durability testing done in accordance with the New Zealand standards show the possibility of using the tested mixture in a temperate climate with the cement content being just $6 \%$. For the full assessment of the durability of rammed earth there is necessary research to be done on the parameters connected to durability, among which the most important seem to be absorbability and freeze resistance.

The analysis of these parameters is being currently performed by the authors. 


\section{REFERENCES}

1. C. T. S. Beckett, C. E. Augarde, "The effect of climate on the unconfined compressive strength of rammed earth" Unsaturated Soils: Research and Applications, pp 287-292, 2012

2. Construction Industries Division of the Regulation and Licensing, New Mexico Earthen Building Materials Code, 14.7.4NMAC Housing and Construction, New Mexico, 2006.

3. M. Hall, "The mechanisms of moisture ingress and migration in rammed earth walls", PHD thesis, Sheffield Hallam University, UK, 2004

4. M. Hall, Y. Djerbib, "Rammed earth sample production: context, recommendations and consistency", Construction and Building Materials 18: 281-286, 2004.

5. H. Houben, H. Guillaud, "Earth construction - a comprehensive guide". Second ed. London: Intermediate Technology Publications, 1996

6. V. Maniatidis, P. Walker, "A review of Rammed Earth Construction", Innovation Project "Developing Rammed Earth for UK Housing", Natural Building Technology Group, Department of Architecture \& Civil Engineering, University of Bath, 2003

7. P. L.Narloch, P.Woyciechowski, Ł.Bieliński, R.Kostro, A. Kruszyński, 2015"Wytrzymałość na ściskanie ziemi ubijanej niestabilizowanej do wznoszenia ścian monolitycznych” Materiały Budowlane 6 '2015 (nr 514)

8. P.L Narloch, P.Woyciechowski, P.Jęda, The influence of loam type and cement content on the compressive strength of rammed earth, ACE , vol LXI, 1/2015, 73-88

9. Standards New Zealand. NZS 4298: 1998 "Materials and Workmanship for Earth Buildings" Standards New Zealand, Wellington, New Zealand,1998

10. Z. Yang, K. Kowalski, J. Olek,, et al., "Effects of Sand Characteristics and Fly Ash Contents on Properties of Flowable Fill”, ACI Materials Journal, Vol. 111 Issue: 5, 543-552, 2014

11. http://www.ceradbud.pl/glina-surowa (accessed 30 April 2015)

\section{LIST OF FIGURES AND TABLES:}

Fig. 1. Recommendations regarding proportions of the mixtures containing cement

Rys. 1 Zalecenia dotyczące proporcji mieszanki z dodatkiem cementu

Fig. 2. Composition of soil mixtures used for research

Rys. 2. Skład poszczególnych mieszanek ziemi użytych w badaniu

Fig.3. Pressure spray test general arrangement according to NZS 4298: 1998

Rys. 3. Układ przy teście metodą sprayu pod ciśnieniem wg NZS 4298: 1998

Fig. 4. On the left: Scheme of the spray nozzle according to NZS 4298: 1998. On the right: The spray nozzle made of plastics using 3D-printing technology

Rys. 4. Po lewej: Schemat końcówki wg NZS 4298: 1998. Po prawej: Końcówka wykonana z tworzywa sztucznego w technologii druku 3D

Fig. 5. Equipment used for research

Rys. 5. Aparatura do badań

Fig. 6. The scheme of the constructed research stand

Rys. 6. Schemat zbudowanego stanowiska badawczego

Fig. 7. Sample testing

Rys. 7. Badanie próbek

Fig. 8. Surface of the samples after the completion of the first stage of research 
Rys. 8. Obraz powierzchni próbek po zakończonym pierwszym etapie badania

Fig. 9. Sample assessment after the cyclical wet and dry testing. To the left: samples from the mixtures stabilized by $6 \%$ of CEM I. To the right: samples from mixtures with the addition of cement. Upper rows: comparison samples. Lower rows: samples after the research

Rys. 9. Ocena próbek po badaniu cyklicznego zawilgocenia i wysychania próbek. Po lewej: próbki z mieszanek stabilizowanych 6\% CEM I, po prawej próbki z mieszanek bez dodatku cementu.

Górne rzędy - próbki porównawcze, dolne rzędy - próbki po badaniu.

Table 1. Properties of loam used for the research - data from the producer

Tabela 1 Właściwości gliny użytej do badania - dane od producenta

Table 2 Mesh analysis of Vistula river sand used for research

Tabela. 2 Analiza sitowa piasku wiślanego użytego do badań

Table 3. The overview of the erodibility tests. The depth of the erosion D is given in [mm]

Tabela 3. Zestawienie wyników badania erozyjności. Głębokości erozji D podano w [mm]

Table 4. Determination of the ratio of susceptibility to water erosion according to NZS 4298: 1998

Tabela 4. Określenie wskaźnika podatności na erozję wg NZS 4298: 1998

Table 5. Classification of the samples according to the erodibility ratio

Tabela 5. Klasyfikacja próbek według wskaźnika podatności na erozję

Table 6. Time of water exposure of rammed earth samples depending on water erodibility ratio

Tabela 6. Czas ekspozycji w wodzie próbek ziemi ubijanej w zależności od wskaźnika podatności na erozję wodną

Table 7. Overview of the research results of cyclical wet and dry appraisal testing

Tabela 7. Zestawienie wyników badania cyklicznego zawilgocenia i wysychania próbek ziemi 


\section{OCENA TRWALOŚCI MURÓW MONOLITYCZNYCH Z ZIEMI UBIJANEJ}

Slowa kluczowe: ziemia ubijana, test erozji, trwałość

\section{STRESZCZENIE:}

Jednym z głównych zagrożeń dla konstrukcji wykonywanych $\mathrm{w}$ technologii ziemi ubijanej jest destrukcja pod wpływem wody. Sposobem na ograniczenie tego niebezpiecznego zjawiska jest uzupełnienie mieszanki lokalnie dostępnych gruntów o składniki stabilizujące. Najczęściej stosowanym składnikiem jest cement portlandzki.

W niniejszym artykule przeanalizowano wyniki badań odporności ziemi ubijanej na erozję wodną. Ze względu na brak krajowych norm dotyczących sposobu badania trwałości ziemi ubijanej, badania zostały wykonane w oparciu o normę nowozelandzką NZS 4298: 1998. Uzyskane wyniki pozytywnie weryfikują możliwość stonowania ziemi ubijanej stabilizowanej cementem w klimacie umiarkowanym. 